\title{
Hepatitis B Infection
}

National Cancer Institute

\section{Source}

National Cancer Institute. Hepatitis B Infection. NCI Thesaurus. Code C3097.

A viral infection caused by the hepatitis B virus. 